\title{
Mediator of DNA Damage Checkpoint Protein 1
}

National Cancer Institute

\section{Source}

National Cancer Institute. Mediator of DNA Damage Checkpoint Protein 1. NCI

Thesaurus. Code C104644.

Mediator of DNA damage checkpoint protein 1 (2089 aa, $227 \mathrm{kDa}$ ) is encoded by the human MDC1 gene. This protein plays a role in checkpoint mediated cell cycle arrest. 